\title{
The Role of the Financial and Macroeconomy Industry on the Development of the Sukuk (Sharia Compliant Bonds) Market: The Case of Indonesia
}

\author{
Datien Eriska Utami \\ Institute Agama Islam Negeri Surakarta, Indonesia \\ Zulfa Irawati \\ Universitas Muhammadiyah Surakarta, Indonesia
}

DOI: https://doi.org/10.36941/ajis-2021-0112

\section{Abstract}

The purpose of this study is to empirically determine whether the banking sector, bond market and conventional stock market as well as macroeconomic variables can influence the development of the Sukuk (Sharia Compliant Bonds) market in Indonesia. This study uses secondary data taken from the Indonesian Stock Exchange, OJK and the Indonesian Statistics Agency. The data used is monthly data from January 2014 to December 2018 which includes the outstanding value of Sharia Compliant Bonds, outstanding bonds value, stock capitalization value and macro variable data in the form of GDP data and export-import trade data. Based on the results of data analysis, it shows that the variables of all financial investment variables, namely the banking sector, the bond market and stocks have a positive effect on the development of the Sharia Compliant Bonds market. in Indonesia, while for the macroeconomic variables only the GDP variable affects the development of the Sharia Compliant Bonds market in Indonesia. The trade-to-foreign ratio variable has no effect on the development of the Sharia Compliant Bonds market in Indonesia.

Keywords: Sharia Compliant Bonds market development, bond market development, stock market, macroeconomic variables

\section{Introduction}

Sharia Compliant Bonds is one of the investment instruments in the financial industry with two main differences compared to conventional bonds, namely first, operating Sharia Compliant Bonds based on Islamic law (Sharia) by paying profit, not interest and second, Sharia Compliant Bonds involves ownership in real assets, (Smaoui, Mimouni, \& Temimi, 2017). In Indonesia, Sharia Compliant Bonds is an investment instrument that provides opportunities for investors to invest. Data shows that the market is very responsive to the issuance of Sharia Compliant Bonds, so that the Sharia Compliant Bonds can be used to build the nation's economy and create social welfare. Almost all of the Sharia Compliant Bonds issued have been completely absorbed by the market, even in some cases it has resulted in excess demand (Endri, 2009).

Based on the Sharia Compliant Bonds issuer, Sharia Compliant Bonds are categorized into corporate Sharia Compliant Bonds and state Sharia Compliant Bonds. Both types of Sharia Compliant 
Bonds have been issued in Indonesia. The company's Sharia Compliant Bonds was first issued by a company in Indonesia since 2002 using the mudharabah principle, namely the 2002 Sharia Mudharabah Indosat Bonds worth IDR 175 billion. Meanwhile, the first state Sharia Compliant Bonds issued by the Indonesian government was in 2008 with the issuance of State Sharia Securities (SBSN) in 2008.

The development of Sharia Compliant Bonds in the world began with the issuance of sovereign Sharia Compliant Bonds or state Sharia Compliant Bonds, but in the following years corporate Sharia Compliant Bonds or corporate Sharia Compliant Bonds dominated. Data from Standard \& Poor's (S\&P) shows that in 2003, sovereign Sharia Compliant Bonds still dominated the global Sharia Compliant Bonds market at $42 \%$ and Sharia Compliant Bonds issued by financial institutions by $58 \%$. However, in 2007, corporate Sharia Compliant Bonds dominated the global Sharia Compliant Bonds market, namely around $71 \%$, financial institutions $26 \%$, and government only $3 \%$. Generally, the issuance of corporate Sharia Compliant Bonds is intended for business expansion, especially by large companies from Middle Eastern and Southeast Asian countries (Endri, 2009).

Meanwhile, the number of Sharia Compliant Bonds emissions in Indonesia is experiencing rapid growth. Based on the OJK report on the Sharia Compliant Bonds market in Indonesia, the rapid development of corporate Sharia Compliant Bonds issuance occurred in 2017, with 137 Sharia Compliant Bonds issuers recorded throughout the year. Data shows that the accumulated value of Sharia Compliant Bonds issuance during 2017 was IDR 26.39 trillion and the number of Sharia Compliant Bonds still in circulation was recorded at 79 as of the end of December 2017 with an outstanding value of IDR 15.7 trillion (www.OJK.go.id). High investor interest is based on the availability of Indonesian government regulations regarding sharia economic activities related to Sharia Compliant Bonds investment, both state and corporate Sharia Compliant Bonds. In addition, there are sharia provisions that underlie the implementation of sharia investment activities, namely the prohibition factor for usury which can increase investor interest in investing in the Islamic financial industry.

Despite the rapid growth of Sharia Compliant Bonds in Indonesia, several new problems have emerged related to current issues, especially regarding the Sharia Compliant Bonds issuance and investment process (Adi \& Evony, 2014). In the previous study, it was stated that some of the problems of the level of development of the Sharia Compliant Bonds could be influenced by the large number of investments offers for other financial instruments. These problems can occur because of the challenges of investors in investing in sharia, especially Sharia Compliant Bonds investment. Amid the growth in other forms of investment in financial instruments, Islamic financial institutions and policy makers are also a problem faced by the Sharia Compliant Bonds market in Indonesia (Adi \& Evony, 2014).

In addition, the development of Sharia Compliant Bonds, which is considered very potential and prospective in Indonesia, is considered very slow compared to the development of the conventional financial industry as a whole. Previous studies have shown that there are many factors that can influence the issuance of Sharia Compliant Bonds in Indonesia (Fitrijanti \& Mujahid, 2009). Several factors that can affect the growth of Sharia Compliant Bonds in a region are macroeconomic factors such as GDP per capita; economic size, trade openness, and the percentage of Muslims have a positive influence on the growth of the Sharia Compliant Bonds market (Ali Said \& Rihab Grassa, 2013).

In its development in particular the global Sharia Compliant Bonds market has experienced an extraordinary growth of an average of $27 \%$ per year in the last two decades and in 2016. Data on Sharia Compliant Bonds issuance by companies and issuance of sovereign Sharia Compliant Bonds on the global market have shown an increase in yields of around \$ 318.5 billion (Islamic Financial Services Industry Stability Report, 2017.) Although the largest Sharia Compliant Bonds market is currently Malaysia, however, the data shows that the Sharia Compliant Bonds market in Indonesia has experienced significant development over the past 3 years.

Meanwhile the global crisis in 2008 has played a key role in the financial industry, both sharia 
and conventional. The existence of a striking gap between Islamic and conventional financial instruments contributed to the relatively positive performance of Islamic finance during and after the 2008 global financial crisis (Hasan \& Dridi, 2011). This indicates that the pace of developing a domestic financial system that is oriented towards the Islamic financial market or the next conventional one is very important. Will the banking-oriented or conventional capital marketoriented markets have an influence on Sharia Compliant Bonds (Smaoui et al., 2017).

This research is a study that attempts to fill the research gap on the impact of the development of a country's financial market on the issuance of Sharia Compliant Bonds on the Sharia Compliant Bonds market, especially in the Indonesian region. This objective is to test empirically whether the banking sector and the bond market as well as the conventional stock market and macroeconomic variables can influence the development of the Sharia Compliant Bonds market in Indonesia?

Some of the expected contributions from this research are first, knowing how the implementation of the Sharia Compliant Bonds market in Indonesia to the banking and capital market financial industry in Indonesia. The Sharia Compliant Bonds market as one of the Islamic investment instruments together with the bond and stock markets can each contribute to the deepening of the financial market of an economy. For example, if the Sharia Compliant Bonds market is underdeveloped, banks may tend to reduce opportunities to invest in deposits which could lead to unhealthy or suboptimal lending. Additionally, an underdeveloped Sharia Compliant Bonds market could force insurance companies and pension funds to invest in short-term securities. A wellfunctioning Sharia Compliant Bonds market allows banks to invest in Sharia Compliant Bonds certificates and hence mitigates information asymmetry, thereby encouraging efficient resource allocation, essential for economic growth (Smaoui \& Nechi, 2017). Second, the existence of a welldeveloped Sharia Compliant Bonds market together with an advanced financial structure can stimulate economic growth through technological innovation and increase labor productivity in the private sector. Third, the basis of Sharia Compliant Bonds investment is risk sharing, meaning that the issuer and investor share the investment risk and share the profit or loss among them based on agreed terms. This Sharia Compliant Bonds risk sharing feature will direct borrowers and lenders to share business risk in exchange for profit sharing, which can spur investment. Sharia Compliant Bonds investment can be an alternative for Muslim investors who do not want to be associated with investments that are prohibited by sharia principles, namely the prohibition of "riba (interest)", which can lead to higher financial inclusion and thereby stimulate investment and economic growth. Fourth, this study can add to the limited literature on Sharia Compliant Bonds investment and serve as a preliminary study that can reveal factors that can influence the development of the Sharia Compliant Bonds market in Indonesia.

\section{Literature Review and Hypothesis Development}

\subsection{Sharia Compliant Bonds Issuance}

Sharia Compliant Bonds is a term that comes from Arabic which describes financial certificates which can be interpreted as bonds in sharia (International Islamic Financial Market, 2018). According to a statement from AAOFI No. 17 of 2010, Sharia Compliant Bonds is defined as a certificate of equal value which is evidence of an undivided share of ownership of an asset, benefit rights and services, or of ownership of a certain project or investment activity.

There are several criteria according to Godlewski, Turk-Ariss, \& Weill, (2013) that at least the elements of the Sharia Compliant Bonds sharia can be seen through first, Sharia Compliant Bonds is a representation of ownership of tangible assets, second, payments to investors must be profit after tax, third, the value paid when the maturity date must reflect the market value of the underlying asset, not the principal value of the investment. In addition, the criteria for Sharia Compliant Bonds based on IFSB 7 state that there are two forms of Sharia Compliant Bonds, namely asset-based and assetbacked Sharia Compliant Bonds. Asset based Sharia Compliant Bonds are Sharia Compliant Bonds 
based on real assets while asset backed Sharia Compliant Bonds are Sharia Compliant Bonds that are attached and backed up by real assets. The Sharia Compliant Bonds construction is based on technical and commercial features attached to each type to meet sharia compliance requirements.

The difference between Sharia Compliant Bonds and bonds the similarities and differences between conventional Sharia Compliant Bonds and bonds, from various points of view, have been carried out by previous researchers. In its legal structure and in Sharī'ah compliance or shariah compliance, Sharia Compliant Bonds and bonds are concluded differently, Ariff \& Safari, (2012). Meanwhile, Sharia Compliant Bonds and conventional bonds are different products in the portfolio aspect that can reduce risk (Ariff \& Safari, 2012; Bhuiyan, Rahman, Saiti, \& Mat Ghani, 2017; Elhaj, Muhamed, \& Ramli, 2015; Ibrahim, 2015; Saad, Haniff, \& Ali, 2016; Warsame \& Ireri, 2016). Meanwhile (Godlewski, 2014) tested the difference between Sharia Compliant Bonds and bonds in terms of stock market reactions. In brief, it can be concluded that the main difference between Sharia Compliant Bonds and bonds is that Sharia Compliant Bonds must be applied by paying attention to and following sharia principles, which ensures that Sharia Compliant Bonds are free from the elements of usury and non-halal activities that are prohibited in sharia principles. Types of Sharia Compliant Bonds and the classification of types of Sharia Compliant Bonds according to AAOIFI (The Accounting and Auditing Organization of Islamic Financial Institution) is divided into fourteen types of Sharia Compliant Bonds based on the types of financing in financial assets in accordance with Islamic sharia. Basically, the fourteen types of Sharia Compliant Bonds can be grouped into three major groups, namely: a. Sharia Compliant Bonds based on ijarah contracts (ijarah based Sharia Compliant Bonds) or often called SARA bonds b. Sharia Compliant Bonds based on participation or cooperation (partnership based Sharia Compliant Bonds) are commonly referred to as Islamic joint venture (IJV) bonds c. Buying and selling based Sharia Compliant Bonds (debt based Sharia Compliant Bonds). The types of Sharia Compliant Bonds are divided into the following table:

Table 1: Distribution of Sharia Compliant Bonds Types

\begin{tabular}{|l|l|l|}
\hline $\begin{array}{l}\text { Sharia Compliant Bonds-based } \\
\text { ijarah }\end{array}$ & $\begin{array}{l}\text { Sharia Compliant Bonds-based on } \\
\text { cooperation }\end{array}$ & $\begin{array}{l}\text { Sharia Compliant Bonds-based on } \\
\text { buying and selling }\end{array}$ \\
\hline 1. Sharia Compliant Bonds & 1. Sharia Compliant Bonds mudarabah & 1. Sharia Compliant Bonds murabahah \\
ownership of tangible assets & 2. Sharia Compliant Bonds musyarakah & 2. Sharia Compliant Bonds salam \\
2. Sharia Compliant Bonds on & 3. Sharia Compliant Bonds wakalah & 3. Sharia Compliant Bonds istishna \\
beneficial value ownership & 4. Sharia Compliant Bonds muzaraah & \\
3. Sharia Compliant Bonds of & 5. Sharia Compliant Bonds musaqah \\
Services ownership & 6. Sharia Compliant Bonds mukharabah & \\
\hline
\end{tabular}

Based on the financial asset contract in the secondary market, the types of Sharia Compliant Bonds are classified into two categories, namely tradable Sharia Compliant Bonds and non-tradable Sharia Compliant Bonds. (Tariq, 2004). The Sharia Compliant Bonds that can be traded include mudharabah Sharia Compliant Bonds, musyârakah Sharia Compliant Bonds and ijarah Sharia Compliant Bonds. Meanwhile, the Sharia Compliant Bonds that are not traded include the Istishna Sharia Compliant Bonds and / or murabahah and salam Sharia Compliant Bonds. According to Azmat, Skully, \& Brown, (2014a) which was adopted from (Usmani, 2008), the characteristics of each bond if it is concluded that it is divided into IJV bonds which are based on the principle of mudharabah so that they are called Sharia Compliant Bonds mudharabah, SARA bonds, namely Sharia Compliant Bonds which are based on ijarah contracts so that referred to as Sharia Compliant Bonds ijarah, and debt bonds which are based on the principle of murabahah so that they are called murabahah Sharia Compliant Bonds. In Indonesia, especially for Sharia Compliant Bonds issued by companies, the types of Sharia Compliant Bonds that have been issued since 2004 are mudharabah Sharia Compliant Bonds and ijarah Sharia Compliant Bonds, which are types of Sharia Compliant Bonds traded on the secondary market. 


\subsection{Hypothesis Development}

The growth of the financial market begins with the important role of banks in financing companies that are innovative and stimulate productivity. Since then, many studies have produced strong evidence that financial development is beneficial for economic growth. Levine (1997) rekindled interest in the relationship to growth in financial markets. The study by Levine provides strong evidence that financial development is positively correlated with economic growth.

The presence of a well-developed banking system can actually be a complement to the development of the Sharia Compliant Bonds market, however, because banks play an important role in the economy as an intermediary in financing which is much needed by the financial market, a more sophisticated banking system is likely to eliminate the Sharia Compliant Bonds market from market share. finance.

Hypothesis 1: The banking sector has a negative effect on the development of the Sharia Compliant Bonds market or the role of the banking sector and the Sharia Compliant Bonds market is to replace one another.

Although conventional bonds can compete with Sharia Compliant Bonds and may hinder their development, the bond market can provide the necessary infrastructure for Sharia Compliant Bonds issuance and trading. In addition, the disintermediation generated by the bond market can accelerate the development of the Sharia Compliant Bonds market (Smaoui et al., 2017). Thus, the bond market is expected to complement the Sharia Compliant Bonds market.

Hypothesis 2: The conventional bond market has a positive effect on the development of the Sharia Compliant Bonds market or the roles of the bond market and the Sharia Compliant Bonds market are complementary.

Meanwhile, a well-functioning stock market can reduce asymmetric information and improve corporate governance thereby increasing the company's capital capitalization (Smaoui \& Khawaja, 2017). In addition, the increasing level of investor knowledge about market securities is also expected that the development of the bond and stock market is conducive to the growth of the Sharia Compliant Bonds market.

Hypothesis 3: The stock market has a positive effect on the development of the Sharia Compliant Bonds market or the role of the stock market and the Sharia Compliant Bonds market in Indonesia is complementary.

Many previous studies show that there is a relationship between the issuance of Sharia Compliant Bonds and economic growth. At least studies conducted by (Levine, 2004; Thumrongvit, Kim, \& Pyun, 2013) show that there is a relationship between the development of the stock market and the bond market and the country's economic growth. If Sharia Compliant Bonds is one of the financial instruments in the financial market in a country, economic growth in a country can affect the development of the Sharia Compliant Bonds market in a country.

Hypothesis 4: Economic growth as measured by GDP and the ratio of foreign trade has a positive effect on the Sharia Compliant Bonds market.

\section{Research Methodology}

\subsection{Data}

The type of data used in this research is entirely secondary data obtained from the Financial Services Authority, the Central Bureau of Statistics, Bank Indonesia and the Indonesia Stock Exchange. The data used are monthly time series data from January 2014 to December 2018. There are four independent variables in this study, namely banking financing, development of the bond market and development of the stock market as well as macro variables in the form of gross domestic product (GDP) on purchasing power parity and the state's export-import open trade system. The dependent variable in this study is the development of Sharia Compliant Bonds with a measure of the 
outstanding value of corporate Sharia Compliant Bonds in Indonesia. The definition and measurement of variables in this study are:

Table 2. Operational Definition of Variables

\begin{tabular}{|l|l|c|}
\hline Variables Definiton & Size & Symbol of Expectation \\
\hline Dependent Variable & \\
\hline Sharia Compliant Bonds Market Development & Sharia Compliant Bonds market capitalization to GDP & \\
\hline Independent Variable & Credit to the private sector by commercial banks to GDP & - \\
\hline Banking sector (Bank) Financing & Bond market capitalization to GDP & + \\
\hline Development of the bond market (Bonds) & Stock market capitalization to GDP & + \\
\hline Stock market developments (Stocks) & The amount of GDP in purchasing power parity & + \\
\hline Size of the economy (GDP) & The ratio of exports and imports to GDP & + \\
\hline Foreign trade (Exports, Imports) &
\end{tabular}

Empirical Model The empirical model in this study was generated through the ordinary least square regression analysis method. The method used to analyze the role of the banking sector and the bond and stock market on the Sharia Compliant Bonds market development is the ordinary least square multiple linear regression method. The empirical model for this research is:

Sharia Compliant Bondst $=\alpha+\beta_{1}$ Bank $1+\beta_{2}$ Obligasi $2+\beta_{3}$ Saham $_{3}+\beta_{4}$ GDP $_{4}+\beta_{5}$ Ekspor 5 $+\beta 6$ Impor $6+\varepsilon t$

Empirical Results and Discussion Descriptive Statistic Development of the financial industry in Indonesia. The development of Sharia Compliant Bonds in Indonesia since its inception has shown a fluctuating trend. The success of investing in the Sharia Compliant Bonds at the beginning of its establishment has made the Sharia Compliant Bonds market more vibrant in the last decade. The large number of investors who believe in the type of Sharia Compliant Bonds investment and the large amount of investment issued by the issuer in the form of Sharia Compliant Bonds issuance make Sharia Compliant Bonds an attractive investment alternative to consider. Some of the factors that may have contributed to the increase in investment are thought to be developments in banking sector financing and developments in the stock market. Currently, there are 104 corporate Sharia Compliant Bonds issuances in Indonesia, issued by 22 corporate Sharia Compliant Bonds issuing companies in Indonesia. A sharp increase occurred throughout 2018, namely as much as Rp. 22 billion, an increase of almost 30\% from 2017 which was only Rp. 15.7 billion and an increase of $67.5 \%$ compared to 2014 which was only around Rp. 7.1 billion.

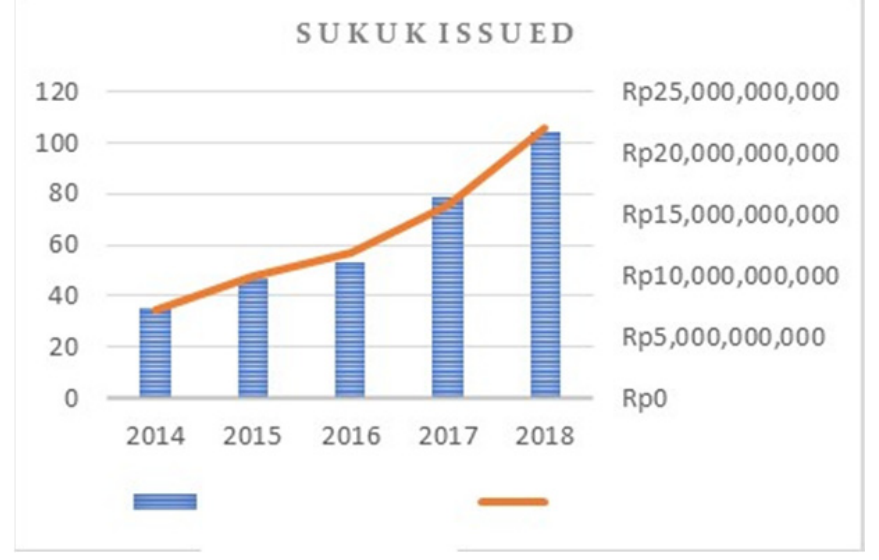

Figure 1. Sharia Compliant Bonds issuance in Indonesia 
Meanwhile in the banking sector, in the last five years, the development of banking sector financing has experienced an upward trend. At the end of 2018, the amount of bank credit in Indonesia was recorded at Rp. 5.3 trillion, an increase of 35\% from 2014 which amounted to Rp. 3.4 trillion.

\section{BANKING}

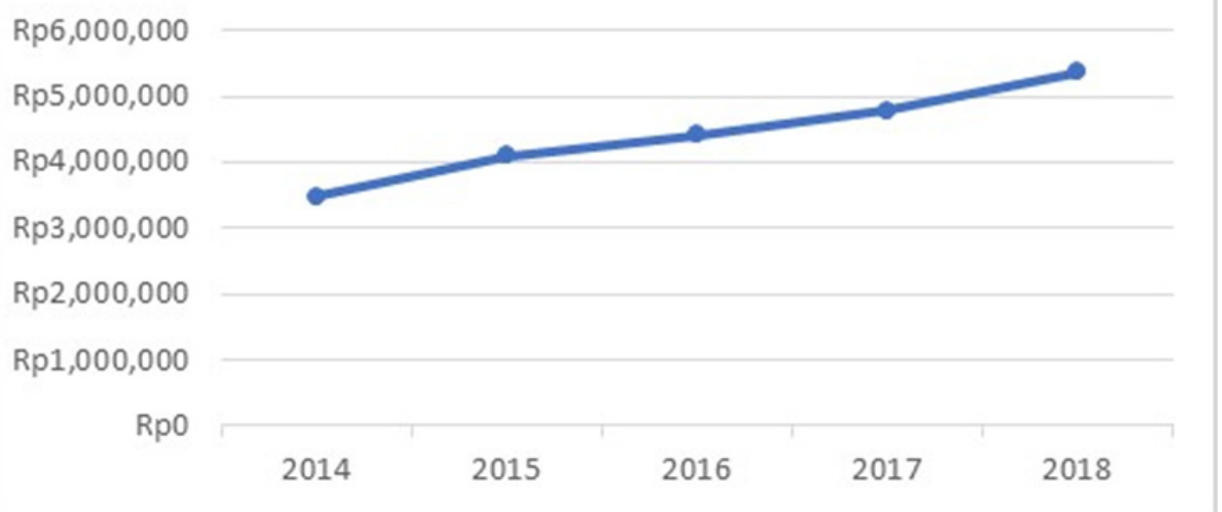

Figure 2. Banking sector financing in Indonesia

As for the bond market, the movement in the value of outstanding bonds for five years has also experienced an increasing trend from year to year, it was recorded that at the end of 2018 the outstanding value of bonds was Rp. 412 billion, which has increased significantly since 2014 with an increase of $47 \%$.

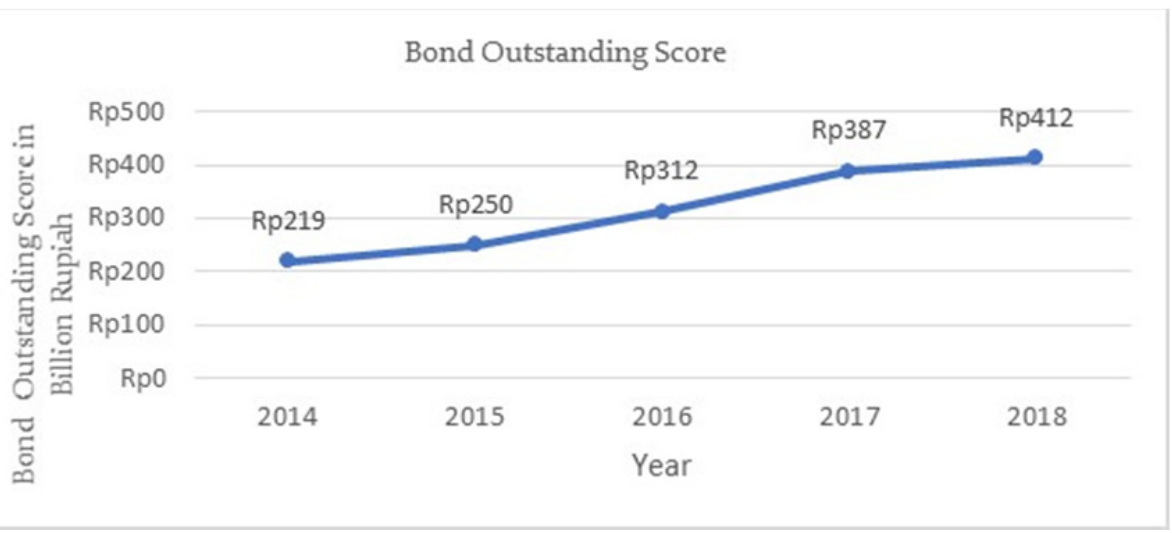

Figure 3. Development of conventional bond market in Indonesia

The movement of the stock market as seen from the value of the stock value capitalization since 2014 has increased fluctuating. An increasing movement was seen throughout 2015 to 2017. Throughout 2018 there was a decrease in the value of stock capitalization compared to the 2017 period of $0.4 \%$. 


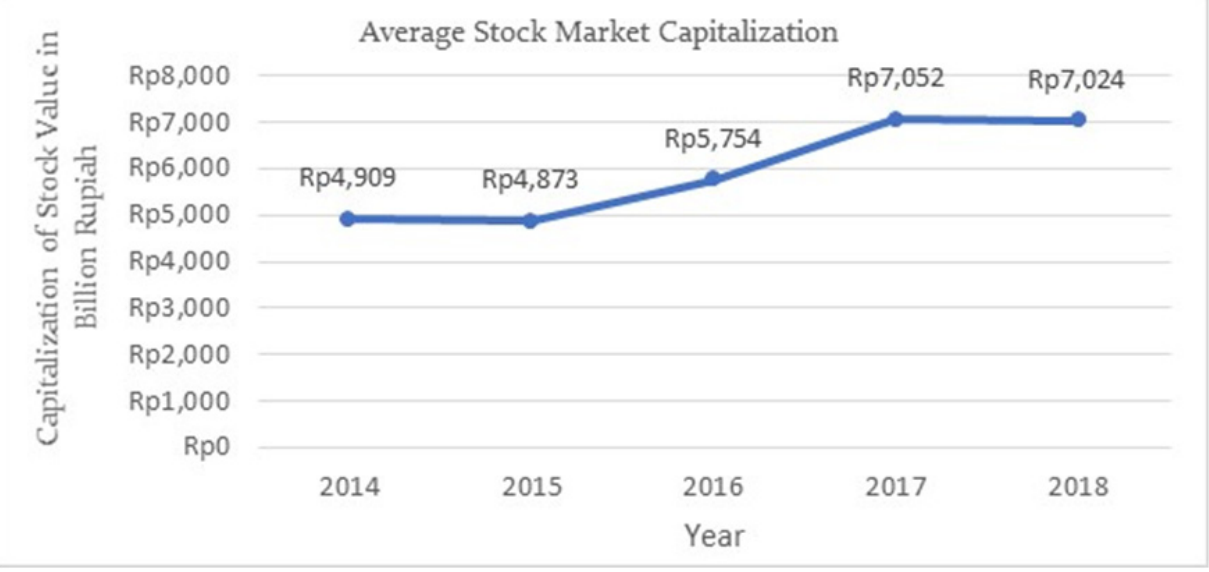

Figure 4. Development of the stock market in Indonesia

The number of investment alternatives offered in both the financial and capital markets can more or less influence investors' interest in investing in the stock market, resulting in a decline in the value of stock capitalization throughout 2018. The data of the dependent variable and independent variable in this research can be described descriptively as follows:

Table 3. Descriptive Statistic

\begin{tabular}{|l|c|c|c|c|c|}
\hline Variable & $\mathrm{N}$ & Mean & Std. Dev & Min & Max \\
\hline Sharia Compliant Bonds & 60 & 0,0037 & 0,0010 & 0,0019 & 0,0065 \\
\hline Bank & 60 & 1,3352 & 0,0288 & 1,2821 & 1,4058 \\
\hline Bonds & 60 & 0,1037 & 0,0217 & 0,0855 & 0,1680 \\
\hline Shares & 60 & 1,8269 & 0,1769 & 1,4612 & 2,8428 \\
\hline GDP (triliun) & 60 & 2,8922 & 0,2811 & 2,6222 & 3,3332 \\
\hline Export Ratio & 60 & 0,0619 & 0,0096 & 0,0423 & 0,0853 \\
\hline Import Ratio & 60 & 0,0593 & 0,0077 & 0,0077 & 0,0874 \\
\hline
\end{tabular}

Note : ** Significant by level o,oo5; *** Significant by level o,o1

Based on the results of data analysis, it was found that the coefficient of determination ( $\left.\mathrm{R}_{2}\right)$ in the model was $90.43 \%$, which indicates that the diversity of the dependent variable could be explained by the independent variable of $90.43 \%$ and $9.67 \%$ explained by other variables outside the model. While the $\mathrm{F}$ test in the research model which shows the model quality test shows significant results, it means that this research model is significantly feasible.

The effect of the independent variable on the variable of Sharia Compliant Bonds development in the regression model analysis above shows that the variable of banking sector financing and the development of bonds has a positive and significant effect at a significance level of $1 \%$, while the variable stock value development has a positive and significant effect at the $5 \%$ significance level on the development of Sharia Compliant Bonds in Indonesia. The GDP level variable in purchasing power parity conditions also has a positive and significant effect at the $1 \%$ significance level, while the foreign trade sector variables, both the export and import variables, have no significant effect on the development of the Sharia Compliant Bonds market in Indonesia. 


\section{Research Discussion}

The results of the regression analysis show that the development of the banking sector has a significant positive effect on the development of Sharia Compliant Bonds in Indonesia. The results of this study do not support the hypothesis that the banking sector has a negative effect on the development of the Sharia Compliant Bonds market in Indonesia. The results of this study also contradict the results of the research presented by (Smaoui et al., 2017), which states that the banking sector is able to act as a substitute for Sharia Compliant Bonds investment. The Sharia Compliant Bonds market can develop further if financing in the banking sector decreases, and vice versa, if the banking financing sector experiences an increasing trend, the development of Sharia Compliant Bonds will decline. However, in the case of the development of Sharia Compliant Bonds in Indonesia, based on the results of the analysis it is shown that the development of Sharia Compliant Bonds in Indonesia has increased along with an increase in financing in the banking sector. The banking sector in Indonesia can mutually reinforce the Sharia Compliant Bonds financial market industry. The increase in the banking sector will be followed by an increase in the Sharia Compliant Bonds market.

However, in the case of the development of Sharia Compliant Bonds in Indonesia, based on the results of the analysis it is shown that the development of Sharia Compliant Bonds in Indonesia is increasing along with an increase in financing in the banking sector. The banking sector in Indonesia can mutually reinforce the Sharia Compliant Bonds financial market industry. The increase in the banking sector will be followed by an increase in the Sharia Compliant Bonds market.

The banking sector can be a multiplier effect for the Islamic finance industry in Indonesia. The greater the ratio of bank financing to GDP, the greater the impact on the country's growth which can be seen from the increase in purchasing power, the business climate and additional investment from the public. Such conditions can ultimately increase economic growth in society. The existence of economic growth will encourage new investment, including Islamic financial investment, including investment in the Sharia Compliant Bonds market. Although the contribution of the Islamic financial system is still below the contribution of the conventional financial system, currently Islamic financial instruments including the Sharia Compliant Bonds have become an important part of national development in Indonesia. The government sharia securities (SBSN) as state Sharia Compliant Bonds have now become an important government instrument.

Other findings of this study indicate that the increase in the development of Sharia Compliant Bonds in Indonesia is also influenced by an increase in the development of the bond market. This means that the bond market in Indonesia can mutually support the Sharia Compliant Bonds market in its development. Historical data shows that in the last five years the upward trend in the Sharia Compliant Bonds market has shown a significant increase in line with the increase in the bond market, although when compared to the value of Sharia Compliant Bonds issuance it is still not as much as the value of bonds issued on the bond market. This means that although the share of the Sharia Compliant Bonds market in Indonesia is still below the bond market, investors have hope for the same return on investment in both the Sharia Compliant Bonds market and the bond market. So that the results of this study support the hypothesis that the development of the bond market has a positive effect on the development of the Sharia Compliant Bonds market in Indonesia.

Meanwhile, the stock market development variable shows a positive and significant effect on the development of corporate Sharia Compliant Bonds in Indonesia. The results of this study also support the hypothesis that the development of the stock market has a positive effect on the development of the Sharia Compliant Bonds market in Indonesia. This means that the stock market in Indonesia can mutually support the Sharia Compliant Bonds market in its development. In this case, capital market investors have the same positive return expectations on Sharia Compliant Bonds investment. Investors have an expectation of profits from the same investment both in the Sharia Compliant Bonds market and the stock market. Sharia Compliant Bonds issuance can be positioned as another promising alternative investment in the capital market apart from stocks and bonds so that the development of Sharia Compliant Bonds has increased sharply in line with the increase in 
the value of stocks and bonds in the capital market.

Unlike the previous antecedent variables which have a positive effect, the macroeconomic variable used in this study is only the GDP value which has a significant influence on the development of Sharia Compliant Bonds in Indonesia. The variables of export and import values do not have a significant effect on the development of Sharia Compliant Bonds in Indonesia. So that in this case the fourth hypothesis is only partially supported by research. In line with research conducted by Smaoui \& Khawaja, (2017) the GDP variable is one of the macroeconomy variables that can support the development of Sharia Compliant Bonds investment in a country. Meanwhile, the foreign trade variable which is indicated by the ratio of export and import values, the results of this study are not supported by research conducted by Smaoui \& Khawaja, (2017).

In an open economy, international trade, namely exports and imports, and the flow of funds between countries are important for a country. Previous studies have shown that there is a positive correlation between export and import growth with economic growth, which in turn can have an impact on increasing a country's investment. International trade can be an important element in the globalization process of a country because it can provide benefits for domestic economic growth with an increase in resource allocation and efficiency as well as an increase in investment including Islamic investment, such as research conducted by Smaoui \& Nechi, (2017). This research actually gives the opposite result because the export and import variables as proxies of international trade variables do not have a significant effect on the development of Sharia Compliant Bonds in Indonesia. International trade should be able to increase economic growth and indirectly affect investment development, but in reality, economic growth in Indonesia is not positively correlated with the booming development of Islamic investment (Rusydiana, A, 2018). The condition is understandable because in Indonesia, although the potential of the Islamic financial market is high, the market share of the Islamic financial industry as a whole is still relatively small, around $1.6 \%$ of the conventional financial industry in Indonesia. Meanwhile, the macroeconomic variable in the form of GDP as a proxy for economic growth shows positive and significant results. The influence of GDP on the development of the Sharia Compliant Bonds market in Indonesia can be explained by an increase in the per capita income of the Indonesian people. Currently, economic development in Indonesia has been driven by an increase in Indonesia's per capita income. The factor of increasing per capita income in Indonesia which drastically in recent years has made the middle-income class increase. World bank data for 2010 and continue to increase until 2018, states that due to increased economic growth due to the commodity boom, every year around seven million Indonesians enter the middle class in Indonesia. This increase has led to consumer power which has fueled growth in domestic and foreign investment since 2010. The investment growth that has occurred as a result of the power of middle-class consumers has also occurred in Islamic financial investment in Indonesia.

Many investors want to invest in Indonesia because of the promising investment market, including in sharia investment in Indonesia. Sukuk as one of the Islamic financial instruments has become a new sharia investment that is starting to be favored by the people of Indonesia. The increasing number of Indonesians who are literate in sharia investment have made sukuk an alternative investment. Especially with the use of technology in the investment world, the ease of doing transactions in sharia investment has made the trend of sharia investment by people in Indonesia starting to be popular.

\section{Recommendations}

The significant effect Sukuk (Sharia Compliant Bonds) is very important to be developed as an alternative way of investment to conventional bonds which are not recommended to be taken by Muslims. The further research is encouraged to conduct comprehensive study regarding Sukuk as the main source for sharia investment in Islamic values and perspective in supporting the national economy. 


\section{Research Limitations}

This research had a few limitations that need to be addressed. First, the research focused on the bond's product of sharia in banking. It exposed on its relations towards stock market and investment only as the main research variable. Second,

\section{Suggestions for Future Research}

1. Expose on Sukuk's impact towards economic growth on middle- low scale industry directly.

2. Comparing Sharia and conventional bonds in the stock market and investment share.

3. The sustainability of Sukuk investment in financial sector by global perspective.

\section{Conclusion}

Based on the results of research that has been conducted regarding the development of the sukuk market in Indonesia, it can be shown that the variables of the banking sector, the bond market and the stock market in Indonesia all have a positive influence on the development of the stock market in Indonesia. This shows that the increase in investment in the banking sector, the bond market and the stock market has also strengthened or complemented the increase in the sukuk market in Indonesia. The sukuk market as one of the existing sharia investments in Indonesia is one of the investments that has increased among other sharia investments and still has the potential to increase in the coming periods. This is also supported by the optimization of the use of technology in the world of Islamic investment which makes investment transactions more developed. Meanwhile the results of research on macroeconomic variables in the form of economic growth with a measure of the value of GDP also have a positive and significant effect on the development of the sukuk market, but for the variables of the trade sector with foreign countries as indicated by the value of the export and import ratios, it does not provide results that affect the development of the sukuk market in Indonesia. Indonesia.

\section{References}

Adi, A., \& Evony, P. (2014). Analisis kesesuaian syariah dalam penerbitan, pelaksanaan, dan. (17).

Ariff, M., \& Safari, M. (2012). Are Sharia Compliant Bonds Securities the Same as Conventional Bonds? Afro Eurasian Studies, 1(1), 101-125. https://doi.org/10.2139/ssrn.1783551

Azmat, S., Skully, M., \& Brown, K. (2014). Issuer's choice of Islamic bond type. Pacific Basin Finance Journal, 28, 122-135. https://doi.org/10.1016/j.pacfin.2013.08.008

Bhuiyan, R. A., Rahman, M. P., Saiti, B., \& Mat Ghani, G. Bin. (2017). Financial Integration between Sharia Compliant Bonds and Bond Indices of Emerging Markets: Insights from Wavelet Coherence and Multivariate-GARCH Analysis. Borsa Istanbul Review. https://doi.org/10.1016/j.bir.2017.11.0o6

Elhaj, M. A. A., Muhamed, N. A., \& Ramli, N. M. (2015). The Influence of Corporate Governance, Financial Ratios, and Sharia Compliant Bonds Structure on Sharia Compliant Bonds Rating. Procedia Economics and Finance, 31(McMillen 2007), 62-74. https://doi.org/10.1016/S2212-5671(15)o1132-6

Endri. (2009). Permasalahan Pengembangan Sukuk Korporasi di Indonesia Menggunakan Metode Analytical Network Process (Anp). 13(3), 359-372.

Fitrijanti, T., \& Mujahid. (2009). Pengaruh Penerbitan Obligasi Syariah (Sharia Compliant Bonds) Perusahaan Terhadap Reaksi Pasar (Survey terhadap perusahaan - perusahaan yang menerbitkan obligasi syariah dan terdaftar di Bursa Efek Indonesia tahun 2002-2009).

Godlewski, C. J. (2014). What Influences Stock Market Reaction to Sharia Compliant Bonds Issues? The Impact of Scholars and Sharia Compliant Bonds Types. (February), 1-26.

Godlewski, C. J., Turk-Ariss, R., \& Weill, L. (2013). Sharia Compliant Bonds vs. conventional bonds: A stock market perspective. Journal of Comparative Economics, 41(3), 745-761. https://doi.org/10.1016/j.jce.2013.02.006 
Hasan, M., \& Dridi, J. (2011). the Effects of the Global Crisis on Islamic and Conventional Banks: a Comparative Study. Journal of International Commerce, Economics and Policy, 02(02), $163-200$. https://doi.org/10.1142/S1793993311000270

Ibrahim, M. H. (2015). Issues in Islamic banking and finance: Islamic banks, Shari'ah-compliant investment and Sharia Compliant Bonds. Pacific Basin Finance Journal, 34, $185^{-191 .}$ https://doi.org/10.1016/j.pacfin.2015.06.002

Levine, R. (2004). Finance Growth Theory Evidence. NBER Working Paper Series, (September).

Rusydiana, A, S. (2018). Hubungan Perdagangan Internasional , Pertumbuhan Ekonomi dan Industri Hubungan Antara Perdagangan Internasional , Pertumbuhan Ekonomi Dan Perkembangan Industri Keuangan Syariah Di Indonesia. Islamic Finance \& Business Review, 4(1), 47-6o.

Saad, N. M., Haniff, M. N., \& Ali, N. (2016). Firm's Growth and Sustainability: The Role of Institutional Investors in Mitigating the Default Risks of Sharia Compliant Bonds and Conventional Bonds. Procedia Economics and Finance, 35(October 2015), 339-348. https://doi.org/10.1016/S2212-5671(16)ooo42-3

Said, A., \& Grassa, R. (2013). The Determinants of Sharia Compliant Bonds Market Development: Does Macroeconomic Factors Influence the Construction of Certain Structure of Sharia Compliant Bonds? Journal of Applied Finance E Banking, 3(5), 251-267.

Smaoui, H., \& Khawaja, M. (2017). The Determinants of Sharia Compliant Bonds Market Development. Emerging Markets Finance and Trade, 53(7), 1501-1518. https://doi.org/10.1080/1540496X.2016.1224175

Smaoui, H., Mimouni, K., \& Temimi, A. (2017). Sharia Compliant Bonds, banking system, and financial markets: Rivals or complements? Economics Letters, 161, 62-65. https://doi.org/10.1016/j.econlet.2017.09.014

Smaoui, H., \& Nechi, S. (2017). Does Sharia Compliant Bonds market development spur economic growth? Research in International Business and Finance, 41(February), $136-147$. https://doi.org/10.1016/j.ribaf.2017.04.018

Tariq, A. A. (2004). Managing financial risks of Sharia Compliant Bonds structures. Loughborough University, UK, (September), 1-86.

Thumrongvit, P., Kim, Y., \& Pyun, C. S. (2013). Linking the missing market: The effect of bond markets on economic growth. International Review of Economics and Finance, $27, \quad 529-541$. https://doi.org/10.1016/j.iref.2013.01.0o8

Usmani, M. (2008). Sharia Compliant Bonds and their contemporary applications. South Africa: Mujlisul Ulama of South Africa, 1-15. Retrieved from http://www.Sharia Compliant Bonds.com/library/education/MuftiTaqiSharia Compliant Bondspaper.pdf

Warsame, M. H., \& Ireri, E. M. (2016). Does the theory of planned behaviour (TPB) matter in Sharia Compliant Bonds investment decisions? Journal of Behavioral and Experimental Finance, 12, 93-100. https://doi.org/10.1016/j.jbef.2016.10.002 